University of Texas Rio Grande Valley

ScholarWorks @ UTRGV

Political Science Faculty Publications and

Presentations

2005

\title{
Trying to Save the Garden: What if "Rat Choice" Hadn't Invaded Public Policy and Public Administration? A Public Administration Satire
}

Terence Garrett

University of Texas Rio Grande Valley, terence.garrett@utrgv.edu

Follow this and additional works at: https://scholarworks.utrgv.edu/pol_fac

Part of the Political Science Commons, and the Public Affairs, Public Policy and Public Administration Commons

\section{Recommended Citation}

Garrett, Terence. "Trying to Save the Garden: What If 'Rat Choice' Hadn't Invaded Public Policy and Public Administration? A Public Administration Satire." Public Voices, vol. 8, no. 1, Jan. 2005, pp. 40-43.

This Article is brought to you for free and open access by the College of Liberal Arts at ScholarWorks @ UTRGV. It has been accepted for inclusion in Political Science Faculty Publications and Presentations by an authorized administrator of ScholarWorks @ UTRGV. For more information, please contact justin.white@utrgv.edu, william.flores01@utrgv.edu. 


\title{
Trying to Save the Garden: What if "Rat Choice" Hadn't Invaded Public Policy and Public Administration?
}

\author{
A Public Administration Satire
}

Terence M. Garrett

\section{Introduction}

The study of public administration is a huge garden of fruits and vegetables. There are a wide variety of different plant species that are beneficial to the public interest. Unfortunately, however, every garden also harbors pests, both of the plant and animal kind. In this essay, the "garden" represents the fruits enjoyed by a democratic public administration and the primary destructive force is the unchecked power of the rat. ${ }^{1}$ The rat represents the worst of capitalist behavior that undermines democracy and public service. First, we will make a simple salad comprised of fruit, nuts, and vegetables. Second, we will be looking at the behavior of the rat in undermining the produce from the garden. Finally, we will conclude the short essay with a possible solution to the problem of the rat.

\section{Making Salad with a Sample of Fruits and Veggies}

Okay. So it is bad enough that we have had to make do with a rather odd lot of vegetables and fruits in our public administration garden. Wilson (1887) introduced "papaya" through his politics/administration dichotomy that has had a lasting effect on the "artificial separation" legacy found in the discipline.

Fruit note: Papaya is a tropical fruit that grows on a palm tree, that when cut open the inside resembles a cantaloupe. The resemblance, though, is quickly lost on the victim who opens it as the insides smell like a putrid trash can. Some people, still, like the fruit and claim that it is tolerable when one squeezes a lime on it to alleviate the initial unpleasantness of the odor. In South Texas, natives have been known to use the crushed seeds of the fruit to tenderize meat and to make brisket seasoning. The comparison with Wilson here is good because the politics/administration dichotomy on its face is a stinky idea until further 
explained and coaxed when other fruits and vegetables are added. A word of caution is in order: it is still papaya. ${ }^{2}$

So, modern American public administration (Waldo's classical approach, see below) had its humble beginnings in the papaya fruit. ${ }^{3}$ This is hardly sufficient to sustain us in our garden quest.

Dwight Waldo introduces us to "lettuce," as in let us not forget where we have come from in public administration. Lettuce comes in a number of varieties including iceberg and romaine. As Fry (1998) reminds us, Waldo remains an important force in questioning public administration at its roots. Is PA a discipline, a profession, a science, or an enterprise (241)? Lettuce is a basic component our salad and holds it together. Waldo asks: "What is Public Administration" and this question, similarly provides us with a strong beginning.

Vegetable note: lettuce is used extensively in tossed salads and in Caesar salads, for example. There isn't a whole lot of nutrition in the vegetable, but it is popular with most folks nonetheless. It is also a good source of roughage.

When examining the contents of our garden, we must not overlook the importance of apples. In particular, the "Paul Appleby" variety is critical here. Like a big red delicious apple, Appleby reminds us that government is different from every other activity in society. Politics is supreme and should never be ignored or downplayed when engaging in the study of public administration and in the conduct of analyzing public policy. It is difficult to imagine a Waldorf salad without the apple!

Fruit note: Apples come in several varieties including Granny Smith, Rome, and Jonathon, to name a few. Apples are highly nutritious and very important to good public health. Remember the old saying, "An apple a day..."

No salad would be truly complete without nuts (Waldorf or otherwise). Herbert A. Simon (1957) answers the call from the "intrusiveness of economics"4 by coming up with the concept of "satisficing," a rather nutty idea that still bears proper consideration. In response to the "rats," (see more below) Simon rebuts the invasive idea from microeconomics (a basis in rat thinking) that humans are completely imbued with the tendencies of selfishness, have all-knowing capabilities of choices available, and are utility maximizing. Simon is, however, perilously close to providing too much food for the rats in terms of the kindred spirit "rationality" that his and their theories share in common.

Dry fruit note: Nuts are exceedingly healthful unless consumed in too large quantities, then that makes one potentially too fat. Cautionary second note: It is also a favorite of rats and other rodents and serves as a gateway into the garden.

Olives come next in our salad. Charles Lindblom (1959) bears fruit with his analysis of the science of "muddling through." Lindblom gives us the "root" approach: a rational comprehensive change in policy analysis as a means to examine changes in public policy. He also refers to the "branch" approach: successive limited comparisons, or the incremental 
approach to understanding policy analysis. Both metaphors are analogous to our olive tree in the public administration garden.

Fruit note: Olives take years to develop but are ultimately well worth the wait. Again, as in the other fruits and vegetables noted above, they come in a wide and delicious variety.

There are numerous other examples of fruit and vegetables that we could go into, but we have enough ingredients for our simple salad. A recap shows that we have papaya, lettuce, apples, and olives. Throw these things into a bowl, sprinkle some feta cheese, add croutons and raspberry vinaigrette dressing, pour two glasses of pinot noir, etc., then voila'! We would have had a great meal, in principle, from our PA garden. But then, of course, there is the problem of the rat.

\section{In Comes the Rat}

At this point we should be enjoying our repast. Unfortunately, the rats have devoured most of the salad before we get it. Rats use: (1) tools such as vouchers; (2) the idea of treating citizens as customers; (3) the assumption that people are always greedy and selfish and not motivated to serve the public good; (4) the notion that individuals are utility-maximizers; (5) motivation techniques that the people in a society are profit-driven; and, (6) the false notion that government services provided by the public sector are always inherently inferior to services provided by the private sector. ${ }^{5}$ Rats will nest in the papaya trees, eat the fruit, and pretend that there is a literal separation of politics and administration, the whole time knowing that their behavior in administration is inherently political. Similarly, the rats hate olives and apples and try to destroy the trees by eating their roots. When the trees are gone, the rats deny that they ever existed. The nuts are allowed to exist, but not flourish. It is rational behavior to do it after all.

\section{Solution to the Problem of the Rats}

Quick, call in the rat terriers!

\section{Moral of the Story}

Too many rats destroy the garden. Unchecked rat thinking is also unhealthy for the long-term survival of good public service. 


\section{References}

Appleby, Paul (1973). Government is Different. In Classics of Public Administration, Fourth Edition, (1997) edited by Jay M. Shafritz and Albert C. Hyde. Fort Worth: Harcourt Brace College Publishers, 122-6 [originally published in 1945].

Fry, Brian R. (1998). Mastering Public Administration: From Max Weber to Dwight Waldo. New York: Chatham House Publishers.

Lindblom, Charles E. (1959). The Science of "Muddling Through.” In Classics of Public Administration, Fourth Edition, (1997) edited by Jay M. Shafritz and Albert C. Hyde. Fort Worth: Harcourt Brace College Publishers, 198-208.

Simon, Herbert A. (1957). Administrative Behavior: A Study of Decision-Making Processes in Administrative Organization, Second Edition. New York: The Free Press.

Wilson, Woodrow (June 1887). The Study of Administration. In Political Science Quarterly, volume 2 .

\section{Notes}

${ }^{1}$ Rats serve a useful purpose when properly balanced in an ecological system. However, if they are allowed to run amuck, there will be trouble brewing in the garden.

${ }^{2}$ A further explanation is in order here. Papaya resembles cantaloupe when it is cut open, but the smell is quite bad in comparison. Squeezing a lime on the remaining fruit (after the seeds have been removed) makes it much more palatable.

${ }^{3}$ Please note that Woodrow Wilson is not a fruit. Rather, his ideas represent a papaya in our metaphorical garden. For that matter, no one else depicted in this parable is a fruit, nut, or a vegetable, respectively.

${ }^{4}$ Rat choice theory is at its heart a variation of microeconomic theory. It is intrusive in the sense that it permeates thinking in our metaphorical garden to the point that everything good about public administration is lost.

${ }^{5}$ Rat ideology is pervasive in American society and represents one of the greatest challenges to democratic public service.

Dr. Terence M. Garrett is a professor with the Political Science Department, University of Texas-Pan American. 